This item was submitted to Loughborough's Research Repository by the author.

Items in Figshare are protected by copyright, with all rights reserved, unless otherwise indicated.

\title{
An empirical investigation of the determinants of the location of foreign direct investment in the Central and Eastern European countries using multilevel data
}

\section{PLEASE CITE THE PUBLISHED VERSION}

\section{PUBLISHER}

(C) Loughborough University

\section{VERSION}

VoR (Version of Record)

LICENCE

CC BY-NC-ND 4.0

\section{REPOSITORY RECORD}

Rasciute, Simona, Eric J. Pentecost, and Helena Marques. 2019. "An Empirical Investigation of the Determinants of the Location of Foreign Direct Investment in the Central and Eastern European Countries Using Multilevel Data”. figshare. https://hdl.handle.net/2134/4178. 
This item was submitted to Loughborough's Institutional Repository (https://dspace.lboro.ac.uk/) by the author and is made available under the following Creative Commons Licence conditions.

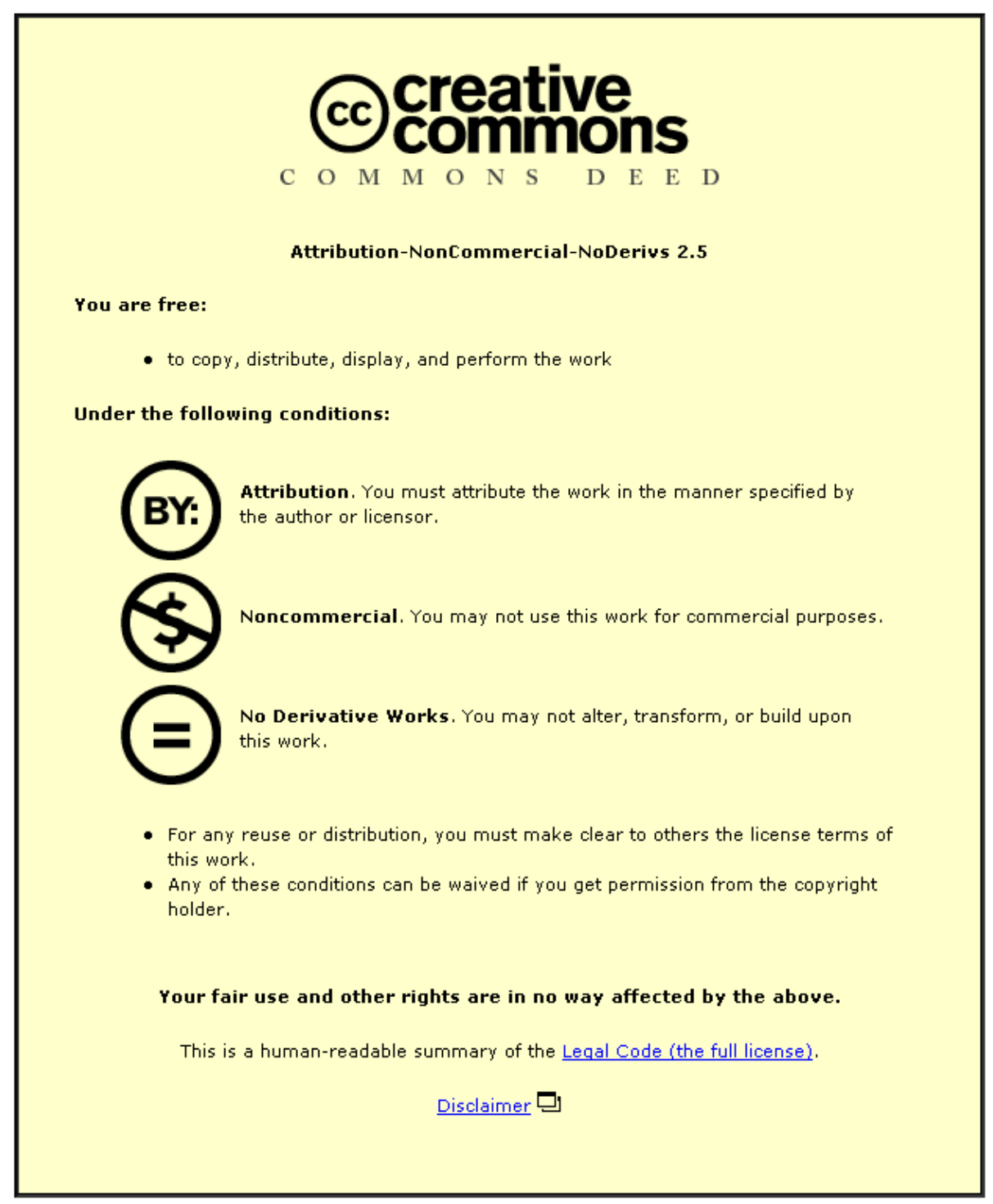

For the full text of this licence, please go to: http://creativecommons.org/licenses/by-nc-nd/2.5/ 
ISSN 1750-4171

\section{DEPARTMENT OF ECONOMICS}

\section{DISCUSSION PAPER SERIES}

\section{An Empirical Investigation of the Determinants of the Location of Foreign Direct Investment in the Central and Eastern European Countries Using Multilevel Data}

Simona Rasciute Eric J. Pentecost Helena I. Marques

WP $2007-22$ 


\title{
An Empirical Investigation of the Determinants of the Location of Foreign Direct Investment in the Central and Eastern European Countries Using Multilevel Data
}

\author{
by \\ Simona Rasciute, Eric J. Pentecost and Helena Marques \\ Department of Economics \\ Loughborough University \\ Loughborough \\ Leicestershire \\ LE11 3TU \\ UK
}

September 2007

Corresponding Author: Eric Pentecost, Department of Economics, Loughborough University, Loughborough, Leicestershire, LE11 3TU, UK. Tel: +44-1509-222734; Fax: +44-1509-222310; Email E.J.Pentecost@lboro.ac.uk 


\title{
An Empirical Investigation of the Determinants of the Location of Foreign Direct Investment in the Central and Eastern European Countries Using Multilevel Data
}

\begin{abstract}
This paper employs a novel multi-level data set and a multinomial logit model - to examine the factors explaining 1,223 foreign investment location decisions by firms in the EU(15), Japan, Norway, Russia, Switzerland and the US in 12 Central and Eastern European countries (CEECs). The highly significant empirical results, based on a general underlying model of imperfect competition, show that the responsiveness of foreign direct investment in the CEECs to country-level variables differs significantly both across sectors and across firms of different sizes and profitability. In particular, in addition to the traditional importance of market size and distance, firm size and the effective corporate tax rate are also important for the location of investment.
\end{abstract}

JEL classification Nos: F23, P33

Keywords: Multi-level data, foreign direct investment, multinomial logit model 


\section{Introduction}

The existing empirical literature on the determinants of foreign direct investment (FDI) has tended to focus either on macroeconomic (i.e. country) characteristics or microeconomic (i.e. firm and industry) characteristics. The traditional approach to the determinants of FDI was to take a macroeconomic perspective such that the location of FDI was based on portfolio theory (see for example, Ailber, 1970; Prachowny, 1972) or investment theory, where market size or growth were of fundamental importance (Boatwright and Renton, 1975; Kwack, 1972). More recent extensions of this macroeconomic approach have been to emphasise the role of wage rates or wage differentials (Culem, 1988; Goldsbrough, 1979) or the role of FDI in establishing export platforms (Barrell and Pain, 1996) or as a way of avoiding exchange rate fluctuations (Barrell and Pain, 1996; Cushman, 1985).

A second distinct strand of the FDI literature has come from the intersection between industrial organisation theory and trade theory especially with introduction of scale economies, imperfect competition and product differentiation (see Markusen and Svensson, 1985). This approach is primarily microeconomic in nature and has emphasised the role of firm or industry-level attributes as determinants of FDI, although more recently, agglomeration economies have also been considered important for FDI decisions (Krugman, 1991). Locating close to other firms results in two counteracting effects: technological and pecuniary externalities and competition among the firms in the market. There is no consensus in the literature as to which force is stronger. Firms may prefer to enter the market that already has a large pool of workers and firms, even if they forgo some monopoly power (Amiti and Pissarides, 2005). Allowing MNEs to enter 
foreign markets and to establish plants, however, increases the demand and the price for capital in that country, reducing factor price differences and the tendency towards agglomeration (Markusen and Venables, 2000). Furthermore, agglomeration economies can have a different effect on heterogeneous firms. Firms with the best technologies, human capital, suppliers and distributors will have little motivation to cluster geographically, as their technologies, human capital, suppliers and distributors will spill over to competitors, and only firms with the weakest technologies, human capital, suppliers and distributors will be willing to cluster (Shaver and Flyer, 2000). Agglomeration effects are also important as are multiple sites to hedge against risk (Wheeler and Mody, 1992). These kinds of models are difficult to test empirically because they require extensive amounts of firm-level data, therefore the approach has typically been to calibrate the model, by assuming some parameter values, and to attempt some numerical simulations (see for example, Markusen and Venables, 1998) Barrios et al., 2004 use panel data set on Greek, Irish and Spanish FDI productivity spillover from a firm level data set.

An alternative empirical approach for these microeconomics-based models has been the use of a discrete choice methodology following Carlton (1983) and McFadden (1974), whereby the location choice of foreign investors, mostly in manufacturing, using discrete choice methodology (see for example,; Becker et al., 2004; Disdier and Mayer, 2004; Guimaraes et al., 2000; and Head et al., 1999).

Since the existing literature has found both macroeconomic and microeconomic determinants of FDI to be relevant, this paper generalizes this literature by allowing the FDI decision to depend on both to country (macroeconomic conditions) and firm or 
industry characteristics. In addition this paper also derives a measure of the effective corporate tax rates in the relevant host countries, which is found to have a significant effect on the investment location decision. To this end this paper uses a discrete choice methodology and a multi-level data set. This is in contrast to the traditional ordinary least squares (OLS) time series or panel data techniques where the explanation of t4h size of investment at the country level by industry and firm level variable is limited. The methodology is applied to the location choices of foreign direct investment (FDI) decisions of firms in the EU(15), Norway, Switzerland and the US into 12 Central Eastern and European Countries (CEECs), by using a multi-level data set - that is a data on countries, industries and firms - to simultaneously estimate the extent to which these different level factors determine the location choices of the foreign direct investment.

The rest of the paper is set out as follows. Section 2 sets out the model of location choice, from both a statistical and economics perspective in particular, drawing on the results of the new trade theory and theories of imperfect competition. Section 3 discusses the data set and explains the construction of the variables that are used in the estimated model to explain the choice of investment location. Section 4 reports the estimation results and Section 5 concludes.

\section{The Location Choice Model}

\subsection{The statistical model}

A foreign firm, $i$, is faced with the choice of locating its investment in a particular Central and Eastern European country (CEEC), $c$, from a set of $C$ CEECs, according to the expected level of profit $\left(\pi_{c i s}\right)$ to be earned in that location in sector (industry), $s$, is: 


$$
\pi_{c i s}=\beta^{\prime} z_{c i s}+\varepsilon_{c i s}
$$

where $z_{c i s}$ is a vector of country and industry characteristics for the firm which determine the level of profit, $\beta^{\prime}$ is a vector of parameters and $\varepsilon_{c i s}$ is an error term. If the firm chooses country $c$ it is assumed that $\pi_{c i s}$ is the maximum among the $C$ alternative locations. Therefore the statistical model is driven by the probability that country $c$ is chosen because

$$
\operatorname{Pr}\left(\pi_{c i s}>\pi_{k i s}\right)
$$

where $k$ is any other location and $k \neq c$. Following McFadden (1974), if and only if the $C$ country disturbances $\varepsilon_{c i s}$ are independent and identically distributed with a Weibull distribution, such that

$$
F\left(\varepsilon_{c i s}\right)=e^{-\varepsilon_{c i s}}
$$

where $e$ is the exponential constant, then

$$
\operatorname{Pr}\left(Y_{c}=c\right)=\frac{e^{\beta^{\prime} z_{c i s}}}{\sum_{c=1}^{12} e^{\beta^{\prime} z_{c i s}}}
$$

is the probability of investment in country c, which is referred to as the multinomial logit model (MNL).

From equation (1) profit depends on the set of factors in the matrix $z_{c i s}$. However, $z_{\text {cis }}$ includes three sets of variables, country-specific variables, sector-specific variables and firm-specific variables. Let $x_{c}$ be the attributes of the choices, which vary across the 
countries, but which are the same for both industries and firms. The second set of factors that are common between investing firms, but which vary across locations and sectors, are defined as $v_{c s}$. A third set of influences that are common between industries, but which vary across investing firms and countries are called $\phi_{c i}$. Therefore the matrix $z_{c i s}$ can be partitioned as $z_{c i s}=\left[x_{c}, v_{c s}, \phi_{c i}\right]$.

Due to the generic nature of firm- and industry-level variables, they have to be interacted with country-level variables in order to introduce variation across the alternatives. Furthermore some firm and industry-specific characteristics on their own cannot explain the location choices and they have to be combined with other factors. The specification of these interaction terms is considered in the next section. The final MNL is estimated using maximum likelihood where the log-likelihood function is:

$$
\log L=\sum_{i=1}^{I} \sum_{c=1}^{C} \sum_{s=1}^{S} n_{c i s} \log \operatorname{Pr}(c)
$$

where $n_{c i s}$ denotes the number of investments carried out by firm $i$, in sector $s$ and in country $c$.

\subsection{The profit model}

From (1) the economic factors that determine the level of profit need to be specified. The after-tax profit in each location is defined as total revenue $(T R)$ less total costs $(T C)$ net of tax and less the costs arising from the institutional, legal, political and macroeconomic environment prevalent in the host country. It can be written as: 


$$
\pi_{c i s}=\left(1-T_{c}\right)\left(\frac{P_{c i s} Q_{c i s}}{\tau_{c d}}-T C_{c i s}\left(Q_{c i s}\right)\right)-G_{c}
$$

where $T_{c}$ is the tax rate in location c, so that total profits are defined to be net of tax and where $P_{\text {cis }}$ is the price received by firm $\mathrm{i}$ in country $\mathrm{c}$ and industry $\mathrm{s}$ from selling output $Q_{c i s}$, and $T C_{c i s}$ are the costs of producing $Q_{c i s}$. Output not only includes the quantity produced for sale in the home country, but also for export to foreign markets. The more liberal the trade regime of the country, the more it will be able to export abroad and the larger will be the quantity $Q_{\text {cis }}$. As a result, the so called "openness" of the country will have a positive effect on $Q_{\text {cis }}$.

"Iceberg" type transport costs $\tau_{c d}$, are assumed between the source country $d$ and host country $c$ (Samuelson, 1954). For example, when goods are shipped from country $d$ to country c, only a fraction $1 / \tau_{\mathrm{dc}}$ of the original unit is assumed to arrive $\left(\tau_{c d}>1\right)$. Hence, other things being equal, the more remote locations are at a disadvantage. Finally, $G_{c}$ is a term that captures the costs that firms incur due to the macroeconomic investment environment prevalent in the host countries.

Whilst $T R$ is straightforward (prices adjusted for transport costs times quantity), the $T C$ function requires more careful specification. The minimum total costs in each location are made up of fixed and variable costs, which following the new trade theory can be specified as: ${ }^{1}$

$$
T C_{i c s}\left(Q_{i c s}\right)=\left(w_{c s}^{s}\right)^{\alpha} f_{i c s}-\left(w_{c s}^{u}\right)^{\beta}\left(r_{c}\right)^{1-\alpha-\beta}\left(c_{i c s} Q_{i c s}\right)
$$

\footnotetext{
${ }^{1}$ This is a standard formulation following Krugman (1991), where the total minimum cost is derived from a standard cost minimization problem assuming a Cobb-Douglas production function.
} 
where $w_{c s}{ }^{s}$ is an hourly wage rate of skilled labour in country $c$ and industry s; $w_{c s}{ }^{u}$ is an hourly wage rate of unskilled labour in country $c$ and industry $s, r_{c}$ is a return on capital in country $c$ and the $\alpha$ and $\beta$ parameters are the shares of skilled and unskilled labour in total cost respectively. The first term on the right hand side of (7) represents the fixed costs, so a firm that locates its capital in country $c$ and industry s incurs fixed $\operatorname{cost} f_{i c s}$, of acquiring information about foreign markets, developing appropriate marketing strategies and building distribution networks (Bernard et al., 2004). It is also assumed that skilled labour is allocated to fixed costs (reflecting costs of $R \& D$ ), while capital and unskilled labour are allocated to variable costs (capturing standard production). The relative intensity of factor use varies across industries. MNEs enterprises use foreign capital in the form of foreign direct investment and domestic skilled and unskilled labour, $L^{s}$ and $L^{u}$ respectively.

Substituting (7) into (6) we obtain:

$$
\pi_{c i s}^{*}=\left(1-T_{c}\right)\left(\frac{P_{c i s}}{\tau_{c d}}-\left(w_{i c s}^{u}\right)^{\beta}\left(r_{c}\right)^{1-\alpha-\beta} c_{c i s}\right) Q_{c i s}-\left(1-T_{c}\right)\left(w_{i c s}^{s}\right)^{\alpha} f_{c i s}-G_{c i s}
$$

This specification of the profit function, in contrast to the majority of the current theoretical and empirical literature on FDI, allows for the assumption of homogeneity of firms in different sectors and different countries to be relaxed. This is important, as particular location advantages do not have the same value for all multinational enterprises (MNEs). For example, firms operating in different sectors and firms of different size and profitability benefit from local resources to different degrees. Location advantages vary for MNEs with different characteristics and therefore, the interaction between location 
and firm together with industry attributes, rather than each of the firm and industry factors independently affects location choices.

For a given set of prices, the attributes of the $z_{\text {cis }}$ matrix of FDI determinants can be summarised as follows:

$$
z_{c i s}=z\left(T_{c}, \tau_{c d}, r_{c}, Q_{c} G_{c}, w_{c i s}\right)
$$

where the first five terms are location-specific variables, while the last variable $w_{c i s}$ varies across both countries and industries.

\section{The Data Set and the Variable Specification}

Table 1 gives a summary of variable definitions and sources. There are 1,223 firm-level data observations on FDI flows from firms of 20 market economies (EU15 countries, USA, Japan, Russia, Norway and Switzerland) to the firms in 12 transition economies (the ten new EU member states (except for Malta and Cyprus) plus Bulgaria, Croatia, Romania and Ukraine) from 1997 to 2003. The dependent variable in the MNL is arranged to take a value of one for the chosen alternatives and zero for the rest of the alternatives that an investing firm faces. The dependent variable is a discrete choice indicator of the country in which the investment is made.

The country-specific determinants of FDI into the CEECs can be loosely divided into the traditional determinants and the transition-specific determinants. The transitionspecific determinants are proxied by the risk associated with each host country, $G_{c}$, in equation (9). The institutional, legal and political environment, i.e. transparency and effectiveness of legal system, are important for the decision of foreign investors to locate their capital abroad. The Transparency International Corruption Perception Index (TICP) 
is used as a measure of the extent of corrupt practices in the host country. This index pools information from ten different surveys of business executives, risk analysis and the general public. The TICP index ranks countries in terms of the degree to which corruption is perceived to exist among public officials and politicians and it varies from 1 (high corruption) to 10 (no corruption) $)^{2}$..

The traditional determinants from equation (10) are the market size of the host country, $Q_{\mathrm{c}}$, the rate of return in the host country, $r_{c}$, distance $\tau_{\mathrm{cd}}$, and tax rates $T_{c}$ in the host country. As Table 1 shows, market size is simply the GDP of the country and the rate of return is measured as the long-term return on government bonds. Market access in the investment receiving country does not only depend on market size in the host country, but also on the opportunity to export production to neighbouring countries. As a result foreign investors prefer countries with liberal trade regimes. In order to take this effect into account, the investment receiving country's exports as a percent age of GDP is also included in the estimated model, with the sign of the parameter on OPEN expected to be positive.

Distance can be considered as a measure of the transaction costs of undertaking foreign activities, such as the costs of transport and communications, the costs of dealing with cultural and language differences, the costs of sending personnel abroad, and the informational costs of institutional and legal factors, for example, local property rights, regulations and tax systems (Bevan and Estrin, 2004). These kinds of costs are assumed

\footnotetext{
${ }^{2}$ In order to make the interpretation of the parameter more intuitive the TICP index is multiplied through by minus one, so that the smaller the number the higher risk.
} 
to increase with distance. Distance is measured by calculating a distance between source and host country capitals and expressed in kilometres ${ }^{3}$.

The corporate income tax rate affects the profitability of foreign direct investment and hence influences the location choices of MNEs. Few studies, however, analyse the effect of taxes on the location choices of foreign firms in CEECs (Bellak and Leibrecht, 2005; Carstensen and Toubal, 2004; Clausing and Dorobantu, 2005; Wei, 2000). These studies that do include tax rates as a location choice factor in the CEECs usually use statutory corporate income tax rates, but these rates are not an appropriate indicator of the tax burden especially in the case of FDI, because they do not include all the relevant tax codes (Bellak and Leibrecht, 2005). The effective corporate income tax rates should be used, but the statutory rate is only one of the determinants of the total tax burden. For example, when calculating taxable profits, not all income may be included in the tax base, taxable income can vary due to the amount deducted from gross income, a reduced tax rate may be applied to a certain class of taxpayers, there might be an amount deducted from tax liability, or the payment of tax can be delayed. The tax base is also influenced by depreciation schemes, the treatment of losses and valuation of inventories amongst other things. In this paper, in contrast to other studies, the measure of the tax burden in the 12 CEECs is computed using a macroeconomic backward-looking approach, which calculates the effective corporate income tax rate by dividing tax payments by the respective country's GDP. The approach allows a comparison between different tax systems, taking into account such important aspects as untaxed reserves, risk, tax enforcement and the treatment of losses.

\footnotetext{
${ }^{3}$ The data is available from http://www.indo.com/distance
} 
In addition to these factors in equation (9), three other country-specific factors are included in the empirical model: two dummy variables, one for European Union membership (EUD) and another for a common border (CBD) between the investing and the investment receiving country. A dummy variable for a common border between the source and the host country is included, as it is expected that the host country is more likely to be chosen to locate investment if it shares the border with the source country. Usually countries sharing the same border have similar culture and language and stronger historical ties. Countries that were offered to conclude the negotiations with the European Council in 2002, satisfied the economic (market economy), political (democracy and human rights) and administrative (well-functioning institutions) criteria set at the Copenhagen European Council in 1993. The accession of a CEEC into EU meant free trade with EU member states and the adoption of Western business and legal environment, which provided foreign investors with confidence in success of each country's reforms. As a result, the parameter of EU dummy variable is expected to have a positive sign.

Although, unemployment is not important for the individual firm's profit function, it may still be of significance at the country level as an indicator of labour market flexibility. Countries with high local demand for goods and services and high labour market flexibility are likely to face relatively low rates of unemployment, which may encourage firms to invest in a particular host country. On the other hand, a high unemployment rate may mean that although it is easy to recruit labour, there is low demand locally and labour market rigidities. The impact of unemployment, $u_{c}$, on the investment location decision is therefore strictly ambiguous. 
Industry-level wage rates, $w_{c s}$, are included as a proxy for the average costs of firms and they implicitly assume that workers are not fully mobile across sectors, at least in the short run. The profitability of the firm investing abroad is expected to be higher if the labour costs are lower in the chosen country than in the rest of the destination countries, so the coefficient on labour costs is expected to have a negative sign.

These country-specific factors are represented by the vector $x_{c}$ in Section 2 . The empirical counterpart of that vector of variables is therefore summarised as follows, together with the theoretically expected signs above the variables:

$$
x_{c}=\left[\bar{G}_{c}, \tau_{c d}^{-}, \stackrel{+}{Q_{c}}, \bar{T}_{c}, \stackrel{+}{u_{c}}, \stackrel{+}{E} \stackrel{+}{U}, \stackrel{+}{C B} D, O \stackrel{+}{E} N_{c}, \bar{w}_{c s}\right]
$$

The second group of variables to influence the FDI location decision are those which vary with the sector (industry) as well as by country. Industry-specific explanatory variables also include industry dummy variables for scale-intensive $(S C A)$, science-based $(S C I)$ and traditional sectors $(T R A)$. Scale-intensive sectors include typical oligopolistic, large firm industries, with high capital intensity, extensive economies of scale and learning, high technical and managerial complexity, for example, automobiles, aircrafts, chemicals, petrol and coal products, shipbuilding, industrial chemicals, drugs and medicines, petrol refineries, non-ferrous metals and railroad equipment (MidelfartKnarvik et al., 2000). Science-based sectors, on the other hand, are characterised by innovative activities directly linked to high $\mathrm{R} \& \mathrm{D}$ expenditures, for example, fine chemicals, electronic components, telecommunications, and aerospace (MidelfartKnarvik et al., 2000). Traditional (supplier-dominated) sectors include such industries as textiles, clothing, furniture, leather and shoes, ceramics, and the simplest metal products. 
It is expected that firms operating in science-based industries will employ more skilled labour and pay higher wages that reflect this skill premium. This effect is captured by the interaction term $w_{c s} \times S C I$. In contrast to the science-based industries, which are characterised by high-specialisation and risk, traditional sectors that produce every-daylife products are less vulnerable to changes in demand and therefore, they are less risky. As a result, firms investing in traditional sectors are less likely to be discouraged to invest in countries characterised by higher risk, as higher country-level risk is outweighed with lower risk at the industry-level. This effect is captured by the interaction term $G_{c} \times T R A$. Finally, scale-intensive industries, characterized by large efficiency seeking firms, are more likely to be sensitive to higher corporate income tax rate, as higher revenue means higher taxes paid in absolute terms. The sensitivity of larger firms to the corporate income tax rate is captured by the interaction term $T_{c} \times S C A$.

As a result equation (11) contains three interaction terms between country-level and industry-level dummy variables, such that:

$$
v_{c s}=\left[w_{c s} \times{ }^{+} S C I, T_{c} \times{ }^{-} S C A, G_{c} \times{ }^{+} T R A\right]
$$

It is important to control for firm's size and profitability, as country-specific factors vary for firms of different characteristics. The firm-level variables include the turnover of the firm as a proxy for its size $\left(s_{i}\right)$ and earnings before interest and tax as a proxy for profitability $\left(e_{i}\right)$. Firms of different sizes and profitability are likely to possess different resources and capabilities (Dean et al., 1998). Small firms are frequently characterised by speed, flexibility and niche-filling capabilities due to their structural simplicity and faster decision making, entrepreneurial-orientation and less risk aversion 
(Woo, 1987). As a result, smaller firms may respond quicker to the dynamics of the specific industry environment. On the other hand, large firms, which are usually more profitable, are able to acquire a larger market share by exploiting scale economies, bargaining power, patents and financial resources to deal with shocks and business downturns (Dean et al., 1998). Large firms are therefore expected to dominate scaleintensive sectors and to be more sensitive to market size and efficiency considerations, while small and medium enterprises prefer to invest in countries with strong historical ties and similar culture and language. As a result, larger firms are more likely to invest in more remote countries, and the interaction term $\mathrm{s}_{\mathrm{i}} \times \tau_{\mathrm{cd}}$, is therefore expected to have a positive sign.

The degree of internationalisation is largely determined by the size of the firm, since larger firms tend to be more profitable and productive and higher productivity increases the probability of setting up a foreign affiliate (Buch et al., 2005). More profitable firms are also expected to prefer countries with lower unemployment rates. Workers who stay unemployed for some time, may loose their skills, as a result, more profitable firms are able to pay higher wages to attract workers from other firms. If workers are attracted from different industries, more profitable firms have more resources for the training of the new workers. This effect is captured by interaction term $e_{i c} \times u_{c}$. Thus

$$
\phi_{c i}=\left[e_{i c} \times u_{c}, s_{i} \times \tau_{c d}^{+}\right]
$$


Equations (10), (11) and (12) indicate the specific variables that make up the $z_{\text {cis }}$ matrix and which, in turn determine the overall level of profit of the firm in each location, according to equation (1).

\section{Estimation Results}

The MNL model ${ }^{4}$ is applied sequentially combining all the three levels of data. Specification 1 in Table 2, uses just one layer of data (country-level); specification 2 adds a variable that does not only vary among countries but also among industries; specification 3 augments the model with interaction terms between industry dummies and country-level variables; and finally, in specification 4, interaction terms are added between firm-level and country-level variables ${ }^{5}$. The results reported in Table 2 are consistent across all specifications of the model, with all coefficients of consistent magnitudes, correctly signed and statistically significant (except the EU membership dummy) predominantly at the one per cent level. The preferred model in Table 2 is specification 4, which has the best goodness of fit statistics as shown in the final three of the table, with all variables except one statistically significant at the one per cent confidence interval. This is consistent with the maintained hypothesis of this paper, that all three-levels of data are important in informing the FDI location decision.

\footnotetext{
${ }^{4}$ The model was estimated using Limdep 8 Nlogit 3 software.

${ }^{5}$ Since country-level variables do not vary among the decision-makers they cannot be identified separately from the alternative specific constants (ASCs). As a result, either country-level variables or ASCs have to be excluded. As the reason for estimating the model is to measure the effect of a change in a particular characteristic on the probability of choosing a particular alternative, ASCs are excluded and it is therefore assumed that all relevant characteristics are included in the model. This procedure of dropping the ASCs is very common in environmental economics (see, for example, O'Hara, 2006).
} 
Specification 4 shows that the coefficients for the GDP of the investment receiving country, $Q_{c}$, the distance between investing and investment receiving countries $\tau_{\mathrm{cd}}$, and the dummy variable for common border between the host and the source countries are of expected signs and highly significant. This indicates that the bigger the host country and the closer it is to the source country, the more likely it to be chosen by MNEs to locate investment. Positive and statistically significant coefficient of the dummy variable for common border indicates that a host country sharing a common border with a source country is more likely to be chosen to locate investment than a country, which does not have a common border with the investing country. A negative and statistically significant parameter for unemployment rate indicates that investing firms prefer to invest in countries with lower unemployment rates, possibly reflecting more flexible labour markets. Finally, a positive and statistically significant parameter on the variable Open, and negative and statistically significant parameters on variables $T_{c}(\operatorname{Tax})$ and $G_{c}$ (Risk) indicate that foreign firms are discouraged to invest in countries with less liberal trade regimes, higher corporate income tax rates and higher risk. The parameter of dummy variable $E U D$ appears to be statistically insignificant indicating that the offer for accession countries to conclude the negotiations with the European Council in 2002 is less important than the gradual, long-term process of integration of accession countries into the EU. The parameter of the wage variable is negative and statistically significant, indicating that investors in CEECs also search for a relatively cheap labour force.

The interaction terms between country-level and industry-level variables appear to be statistically significant: the interaction term between the effective corporate income tax rate in the investment receiving country and the dummy variable for scale intensive 
industries $T_{c} \times S C A(\operatorname{Tax} \times$ Scale $)$; the interaction term between industry-level wage in the investing receiving country and the dummy variable for science-based sectors $w_{s c} \times S C I$ (Wage $\times$ Science $)$ and the interaction term between risk in the investment receiving country and the dummy variable for traditional sectors $G_{c} \times T R A$, (Risk $\times$ Tradit). The negative and statistically significant parameter of interaction term $T_{c} \times S C A$ implies that firms operating in scale-intensive industries, characterized by large efficiency seeking firms, are more likely to be sensitive to higher corporate income tax rate, as higher revenue means higher taxes paid in absolute terms. The positive and statistically significant interaction term $w_{s c} \times S C I$ indicates that firms, operating in science-based industries will employ relatively more skilled-labour, as compared to firms from traditional sectors and as a result, will be ready to pay higher wages, which reflect skill premium. The positive and statistically significant interaction term $G_{c} \times T R A$ may be interpreted as showing that firms operating in traditional sectors are less likely to be discouraged from locating their investment in countries characterised by higher risk. Furthermore, higher risk at the country level may be offset by the lower risk at the industry level, as traditional sectors on average are likely to be less risky than scaleintensive industries and, especially, science-based sectors.

The positive and statistically significant interaction term $s_{i} \times \tau_{c d}($ Size $\times$ Dis $\tan c e)$ indicates that in contrast to small firms, which have a preference for locations close to their home base and which prefer to invest in countries with strong historical relationships and low cultural and linguistic barriers, large efficiency-seeking firms are less likely to be discouraged from investing in countries with bigger cultural and linguistic differences and weaker historical ties, in order to minimize the costs of entering 
a foreign market. As a result, larger firms are more likely to invest in the more remote countries. The negative parameter for $e_{i} \times u_{c}(\operatorname{Pr}$ ofits $\times$ Unempl) suggests that more profitable foreign investors can afford to pay higher wages to attract workers from other firms. The statistically significant interaction terms show, that even though FDI to the CEECs can be explained by a number of country-level variables, the responsiveness of FDI to those variables differs across sectors and firms of different sizes and profitability.

The outcome of the model estimation process is a set of choice probabilities for each investor, which can be summed up over all alternatives in order to obtain shares for each alternative. The only information that the estimated parameters of a choice model reveal is the sign and significance of the effect of the associated variable on the choice probabilities. In order to measure the effect of the change of a variable on the change in the probability of choosing a particular alternative, direct elasticities of the choice probabilities with respect to a chosen attribute can be calculated ${ }^{6}$. The calculations by NLOGIT software are based on the point elasticity, which is useful for interpreting small changes in the level of an attribute.

Potentially there are three ways to aggregate elasticities: to use a sample mean of estimated probability for choosing an alternative; to calculate the elasticity for each individual decision maker and weight each elasticity with the decision maker's associated choice probability (probability weighted sample enumeration); or to calculate the elasticity for each individual decision maker without weighting it (averaged over observations, called naive pooling). Louviere et al., (2000) argue that naïve aggregation fails to recognize the contribution of each observation to the choice outcome of each

\footnotetext{
${ }^{6}$ The cross elasticities which measure the percentage change in the probability of choosing a particular alternative in the choice set with respect to a given percentage change in a competing alternative have no sensible interpretation in the case of the MNL model.
} 
alternative and advise using the probability weighted sample enumeration (PWSE) to calculate elasticities for discrete choice models, to avoid the problem where a single observation has a very small estimated probability, making the estimated elasticity of that observation very large, resulting in misspecification.

Table 3 reports the investment share of each alternative location and the estimated PWSE elasticities for GDP, tax and wage variables. The second column of Table 3 shows that Bulgaria represents almost 4 percent of the investment choices, while Poland was chosen just over 30 percent of the time. Interestingly these shares are greater for Poland, the Czech Republic and Hungary - the largest economies and the most advanced in terms of the transition towards the western European economies. In contrast Bulgaria, Croatia and Ukraine have some of the lowest shares, showing that these countries have yet to receive as much FDI from the west as the former group of countries, whose transition was somewhat swifter and accession into the EU earlier.

The direct elasticities for GDP, tax and wage attributes on each of the twelve alternatives are also shown in Table 3. It is expected that an increase in market size would make the location more attractive for foreign investors. For example, one percent increase in Bulgaria's GDP, increases the probability of selecting the country as an investment location by about 0.2 percent. The estimated GDP elasticities are inelastic for all location alternatives, except for Poland. A higher corporate income tax rate is expected to have a negative effect on the investment location choices of foreign firms. For example, the rise in the corporate income tax rate by one per cent in Hungary will decrease the probability of selecting the country to locate investment by about one per cent. Although the estimated tax elasticities are inelastic for most countries, the 
exceptions being Croatia, and perhaps Slovenia, which has an absolute value close to unity, the tax elasticities are in general larger than the corresponding GDP elasticities for most countries the exceptions being Croatia, the Czech Republic and Poland. This suggests that a unit rise in the effective tax rate is a more important determinant of FDI location than a similar unit increase in GDP. This is perhaps reflects the fact that multinational corporation prefer to locate in lower tax countries and to supply neighbouring higher tax countries by exporting.

Higher wage rates in the host country are also expected to have a negative effect on the investment location choices of MNEs. The estimated WAGE elasticities are, however, highly inelastic for all 12 CEECs with the exception of Slovenia. Although many previous studies investigating the investment choices of MNEs in the CEECs have concluded that lower wage rates in the CEECs is one of the principal factors attracting foreign investment, the calculated impact elasticities imply that the FDI decision is not very responsive to wage changes. For example, a decrease in the wage rate in Bulgaria by 1 percent will increase the probability of selecting Bulgaria as an investment location only by 0.2 percent.

\section{Conclusions}

In this paper, using a MNL model and a multi-level data set, we have shown that the investment location decision with respect to FDI in the CEECs is complex and depends on country, industry and firm-specific characteristics. Local market size together with the institutional, legal and political environment, corporate income tax rate and liberal trade regimes appear to be the main factors influencing where MNEs locate in the CEECs. The 
responsiveness of FDI in CEECs to country-level variables, however, differs across sectors and across firms of different sizes and profitability. For example, the more profitable MNEs are willing to pay higher wages in order to attract workers from other firms, while larger efficiency-seeking firms are less likely to be discouraged to invest in countries with weaker historical ties and larger cultural and language differences. MNEs operating in science-based industries are more likely to invest in a CEEC with higher wage rates, as higher wages reflect the skills, while firms operating in scale intensive industries are more likely to be discouraged to invest in countries with higher corporate income tax rates. Firms operating in traditional sectors are less likely to be discouraged to invest countries associated with higher risk. Firms operating in scale-intensive industries, characterized by large efficiency seeking firms, are more likely to be sensitive to higher corporate income tax rate, as higher revenue means higher taxes paid in absolute terms.

These results cast some doubt on the robustness of earlier empirical studies that focused on either macroeconomic or microeconomic features of the FDI location decision. In particular, they show that although a large number of country and firm characteristics are statistically significant, quantitatively the FDI location decision is not very responsive to the country level variables such as GDP, the tax burden or wage rates, in the receiving countries. One explanation for the small size of the estimated impact effects may be because there are no dynamic effects in this model, which may turn out to be important when cumulated over a long period of time and which can not be captured by this data set. Alternatively, it could be that the FDI decision is largely a strategic decision, rather than a strictly economic decision and that the decision reached is part of the MNE global, rather than regional strategy. In either case the need for more 
disaggregated data over a longer period of time is likely to be necessary to further enhance these results. 


\section{References}

Ailber, R. Z. (1970). A Theory of direct foreign investment. In "The International Corporation" (C. P. Kindleberger, ed.), pp. 17-34. Cambridge Mass.

Amiti, M., and Pissarides, C. A. (2005). Trade and industrial location with heterogeneous labor. Journal of International Economics 67, 392-412.

Barrell, R., and Pain, N. (1996). An econometric analysis of US foreign direct investment. Review of Economics and Statistics 78, 200-207.

Barrios, S., Dimelis, S., Louri, H., and Strobl, E. (2004). Efficiency spillovers from foreign direct investment in the EU periphery: A comparative study of Greece, Ireland, and Spain. Review of World Economics 140, 688-705.

Becker, S. O., Ekholm, K., Jackle, R., and Mundler, M.-A. (2004). Location Choice and Employment Decisions: A Comparison of German and Swedish Multinationals. Series 1: Economic Studies No 08/2005.

Bellak, C., and Leibrecht, M. (2005). Do low corporate income tax rates attract FDI? Evidence from Eight Central- and East European Countries. In "Research Paper Series, Globalisation, Productivity and Technology. Research Paper 2005/43", The University of Nottingham. Leverhulme Centre for Research on Globalisation and Economic Policy

Bernard, A. B., Redding, S., and Schott, P. K. (2004). Comparative Advantage and Heterogeneous Firms. NBER Working Paper Series, Working Paper 10668.

Bevan, A. A., and Estrin, S. (2004). The determinants of foreign direct investment into European transition economies. Journal of Comparative Economics 32, 775-787.

Boatwright, B. D., and Renton, G. A. (1975). Analysis of United-Kingdom Inflows and Outflows of Direct Foreign-Investment. Review of Economics and Statistics 57, 478-486.

Buch, C. M., Kleinert, J., Lipponer, A., and Toubal, F. (2005). Determinants and effects of foreign direct investment: Evidence from German firm-level data. Economic Policy, 53-109.

Carlton, D. W. (1983). The Location and Employment Choices of New Firms - an Econometric-Model with Discrete and Continuous Endogenous Variables. Review of Economics and Statistics 65, 440-449.

Carstensen, K., and Toubal, F. (2004). Foreign direct investment in Central and Eastern European countries: a dynamic panel analysis. Journal of Comparative Economics 32, 3-22.

Clausing, K. A., and Dorobantu, C. L. (2005). Re-entering Europe: Does European Union candidacy boost foreign direct investment? Economics of Transition 13, 77-103.

Culem, C. G. (1988). The Locational Determinants of Direct Investments among Industrialized Countries. European Economic Review 32, 885-904. 
Cushman, D. O. (1985). Real Exchange-Rate Risk, Expectations, and the Level of DirectInvestment. Review of Economics and Statistics 67, 297-308.

Dean, T. J., Brown, R. L., and Bamford, C. E. (1998). Differences in large and small firm responses to environmental context: Strategic implications from a comparative analysis of business formations. Strategic Management Journal 19, 709-728.

Disdier, A. C., and Mayer, T. (2004). How different is Eastern Europe? Structure and determinants of location choices by French firms in Eastern and Western Europe. Journal of Comparative Economics 32, 280-296.

Goldsbrough, D. J. (1979). Role of Foreign Direct-Investment in the External Adjustment Process. International Monetary Fund Staff Papers 26, 725-754.

Guimaraes, P., Figueiredo, O., and Woodward, D. (2000). Agglomeration and the location of foreign direct investment in Portugal. Journal of Urban Economics 47, 115-135.

Head, C. K., Ries, J. C., and Swenson, D. L. (1999). Attracting foreign manufacturing: Investment promotion and agglomeration. Regional Science and Urban Economics 29, 197-218.

Krugman, P. (1991). Increasing Returns and Economic-Geography. Journal of Political Economy 99, 483-499.

Kwack, S. Y. (1972). Model of Us Direct Investment Abroad - Neoclassical Approach. Western Economic Journal 10, 376-383.

Louviere, J. J., Hensher, D. A., and Swait, J. D. (2000). "Stated Choice Methods Analysis and Application," Cambridge University Press, Cambridge.

Markusen, J. R., and Svensson, L. E. O. (1985). Trade in Goods and Factors with International Differences in Technology. International Economic Review 26, 175 192.

Markusen, J. R., and Venables, A. J. (1998). Multinational firms and the new trade theory. Journal of International Economics 46, 183-203.

Markusen, J. R., and Venables, A. J. (2000). The theory of endowment, intra-industry and multi-national trade. Journal of International Economics 52, 209-234.

McFadden, D. S. (1974). Conditional Logit Analysis of Qualitative Choice Behavior. In "Frontiers in Econometrics" (P. Zarembka, ed.). Academic Press.

Midelfart-Knarvik, K. H., Overman, H. G., Redding, S. J., and Venables, A. J. (2000). The Location of European Industry. European Economy - Economic Papers 142, Commission of the EC, Directorate-General for Economic and Financial Affairs (DG ECFIN).

O'Hara, M. E. (2006). Nobody goes there any more... it's too crowded. Estimating congestion effects in sites choice models of recreation. . Binghamton University, Department of Economics. 
Prachowny, M. F. J. (1972). Direct investment and the balance of payments of the United States: A Portfolio approach. In "International Mobility and Movements of Capital" (F. Machlup, W. S. Salant and L. Taskis, eds.), pp. 443-64, New York.

Pusterla, F., and Resmini, L. (2005). Where do Foreign Firms Locate in Transition Countries? An Empirical Investigation. In "The Impact of the European Integration and Enlargement on Regional Structural Change and Cohesion", 5th Framework Programme, European Commission.

Samuelson, P. (1954). The Transfer Problem and Transport Costs, Economic Journal 64, 264-89.

Shaver, J. M., and Flyer, F. (2000). Agglomeration economies, firm heterogeneity, and foreign direct investment in the United States. Strategic Management Journal 21, 1175-1193.

Wei, S. J. (2000). How taxing is corruption on international investors? Review of Economics and Statistics 82, 1-11.

Wheeler, D., and Mody, A. (1992). International Investment Location Decisions. The Case of US Firms. Journal of International Economics 33, 57-76.

Woo, C. Y. (1987). Path-Analysis of the Relationship between Market Share, BusinessLevel Conduct and Risk. Strategic Management Journal 8, 149-168. 
Table 1: List of variables, definitions and sources

\begin{tabular}{|c|c|c|}
\hline Variable & Definition & Source \\
\hline Choice $_{c}$ & $\begin{array}{l}\text { a CEEC, in which firm } \mathrm{n} \text { chooses to locate its } \\
\text { investment over the period of time from } 1997 \text { to } \\
2003 \text { (it gets the value of } 1 \text { if the country received } \\
\text { investment and } 0 \text { otherwise) }\end{array}$ & $\begin{array}{llll}\begin{array}{l}\text { Bureau van } \\
\text { database }\end{array} & \text { Dijk } & \text { Zephyr } \\
\end{array}$ \\
\hline Distance & $\begin{array}{l}\text { distance between the capital cities of the source } \\
\text { country d and the host country c in kilometres }\end{array}$ & http://www.indo.com/distance/ \\
\hline $\mathbf{G D P}_{\mathrm{c}}$ & $\begin{array}{l}\text { GDP of the host country c averaged over the } \\
\text { period of time from } 1997 \text { to } 2003\end{array}$ & IFS \\
\hline Risk $_{c}$ & $\begin{array}{l}\text { Corruption perception index of the host country c } \\
\text { averaged over the period of time from } 1997 \text { to } \\
2003\end{array}$ & Transparency International \\
\hline Unempl $_{\mathrm{c}}$ & $\begin{array}{l}\text { unemployment rate of country c (percentage per } \\
\text { annum) averaged over the period of time from } \\
1997 \text { to } 2003\end{array}$ & IFS \\
\hline $\operatorname{Tax}_{\mathrm{c}}$ & $\begin{array}{l}\text { effective corporate income tax rate in country c } \\
\text { averaged over the period of time from } 1997 \text { to } \\
2003\end{array}$ & $\begin{array}{l}\text { Calculated using data from } \\
\text { OECD Main Economic } \\
\text { Indicators }\end{array}$ \\
\hline Openess $_{\mathrm{c}}$ & $\begin{array}{l}\text { Exports as a percentage of its GDP averaged } \\
\text { over the period of time from } 1997 \text { to } 2003\end{array}$ & $\begin{array}{l}\text { World Development } \\
\text { Indicators (World Bank) }\end{array}$ \\
\hline Border $_{\mathrm{cd}}$ & $\begin{array}{l}\text { a dummy variable that takes a value } 1 \text { if both } \\
\text { source country } d \text { and host country } \mathrm{c} \text { share a } \\
\text { border, and } 0 \text { otherwise }\end{array}$ & constructed \\
\hline$\overline{\mathbf{E U}_{\mathrm{c}}}$ & $\begin{array}{l}\text { dummy variable that takes value } 1 \text { if country c } \\
\text { was offered to conclude the accession negotiations } \\
\text { in October } 2002 \text {, based on the compliance with } \\
\text { the Copenhagen criteria, and } 0 \text { otherwise }\end{array}$ & constructed \\
\hline Scale $_{s}$ & $\begin{array}{l}\text { dummy variable that takes a value } 1 \text { if industry s } \\
\text { is a scale-scale industry, and } 0 \text { otherwise }\end{array}$ & constructed \\
\hline Science $_{\mathrm{s}}$ & $\begin{array}{l}\text { dummy variable that takes a value } 1 \text { if industry } \mathrm{s} \\
\text { is a science-based industry, and } 0 \text { otherwise }\end{array}$ & constructed \\
\hline Tradit $_{s}$ & $\begin{array}{l}\text { dummy variable that takes a value } 1 \text { if industry } \mathrm{s} \\
\text { is a traditional industry, and } 0 \text { otherwise }\end{array}$ & constructed \\
\hline Wage $_{c}$ & $\begin{array}{l}\text { hourly wage rates in the industry s in the country c } \\
\text { averaged over the period from } 1997 \text { to } 2003\end{array}$ & $\begin{array}{l}\text { International Labour } \\
\text { Organisation }\end{array}$ \\
\hline Size $_{n}$ & $\begin{array}{l}\text { turnover of the investing firm } i \text { in Euros in most } \\
\text { recent years }\end{array}$ & $\begin{array}{l}\text { Bureau van Dijk Zephyr } \\
\text { database }\end{array}$ \\
\hline Earnings $_{n}$ & $\begin{array}{l}\text { earnings before interest and taxes of the investing } \\
\text { firm i in Euros in most recent years }\end{array}$ & $\begin{array}{l}\text { Bureau van Dijk Zephyr } \\
\text { database }\end{array}$ \\
\hline
\end{tabular}


Table 2: Specifications of Multinomial Logit Model

\begin{tabular}{|c|c|c|c|c|}
\hline & 1 & 2 & 3 & 4 \\
\hline GDP & $\begin{array}{l}\text { 1.4485* } \\
\{15.913\}\end{array}$ & $\begin{array}{l}\text { 1.4652* } \\
\{17.474\}\end{array}$ & $\begin{array}{l}\text { 1.4794* } \\
\{17.557\}\end{array}$ & $\begin{array}{l}\text { 1.4922* } \\
\{17.698\}\end{array}$ \\
\hline Distance & $\begin{array}{l}-1.6348^{*} \\
\{-16.797\}\end{array}$ & $\begin{array}{l}-\mathbf{1 . 6 6 5 2} \\
\{-17.155\}\end{array}$ & $\begin{array}{l}-\mathbf{1 . 6 7 6 0} * \\
\{-17.202\}\end{array}$ & $\begin{array}{l}-1.7760 * \\
\{-17.377\}\end{array}$ \\
\hline Border & $\begin{array}{l}\mathbf{0 . 3 3 4 3} \\
(2.711\}\end{array}$ & $\begin{array}{l}\mathbf{0 . 3 6 0 5 *} \\
(2.915\}\end{array}$ & $\begin{array}{l}\text { 0.3526* } \\
(2.850\}\end{array}$ & $\begin{array}{l}\text { 0.3692* } \\
(2.981\}\end{array}$ \\
\hline Openness & $\begin{array}{l}\mathbf{0 . 0 1 5 3} \\
\{4.230\}\end{array}$ & $\begin{array}{l}\mathbf{0 . 0 0 9 7 *} \\
\{2.637\}\end{array}$ & $\begin{array}{l}\text { 0.0098* } \\
\{2.662\}\end{array}$ & $\begin{array}{l}\text { 0.0101* } \\
\{2.756\}\end{array}$ \\
\hline Risk & $\begin{array}{l}-\mathbf{0 . 1 7 0 9} * \\
\{-2.776\}\end{array}$ & $\begin{array}{c}-0.3795 * \\
\{-6.056\}\end{array}$ & $\begin{array}{l}-\mathbf{0 . 4 1 1 2} \\
\{-6.430\}\end{array}$ & $\begin{array}{l}-\mathbf{0 . 3 9 4 1} * \\
\{-6.157\}\end{array}$ \\
\hline Return on capital & $\begin{array}{l}\mathbf{0 . 0 1 9 7 *} \\
\{2.310\}\end{array}$ & $\begin{array}{l}\text { 0.0195* } \\
\{8.068\}\end{array}$ & $\begin{array}{l}\text { 0.0192* } \\
\{7.928\}\end{array}$ & $\begin{array}{l}\text { 0.0185* } \\
\{7.579\}\end{array}$ \\
\hline & $\begin{array}{l}-\mathbf{0 . 0 4 6 4} \\
\{-4.231\}\end{array}$ & $\begin{array}{l}-\mathbf{0 . 0 3 3 1} * \\
\{-2.967\}\end{array}$ & $\begin{array}{l}-\mathbf{0 . 0 3 2 6} \\
\{-2.914\}\end{array}$ & $\begin{array}{l}-\mathbf{0 . 0 3 0 2} * \\
\{-2.599\}\end{array}$ \\
\hline 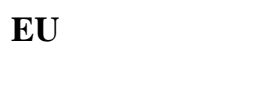 & $\begin{array}{l}-\mathbf{0 . 0 6 4 4} \\
\{-0.403\}\end{array}$ & & & \\
\hline Tax & $\begin{array}{l}-\mathbf{0 . 0 6 0 5 *} \\
\{-4.413\} \\
\end{array}$ & $\begin{array}{l}-\mathbf{0 . 0 5 8 6 *} \\
\{-4.978\} \\
\end{array}$ & $\begin{array}{l}\mathbf{- 0 . 0 4 9 3 *} \\
\{-3.940\} \\
\end{array}$ & $\begin{array}{l}-\mathbf{0 . 0 4 9 1} * \\
\{-3.905\} \\
\end{array}$ \\
\hline Wage & & $\begin{array}{l}-0.3189 * \\
\{-5.986\} \\
\end{array}$ & $\begin{array}{l}-0.3490 * \\
\{-6.199\} \\
\end{array}$ & $\begin{array}{l}-0.3290 * \\
\{-5.859\} \\
\end{array}$ \\
\hline Risk $\times$ Tradit & & & $\begin{array}{c}\mathbf{0 . 1 9 2 1}^{* *} \\
\{1.940\}\end{array}$ & $\begin{array}{l}\text { 0.2039* } \\
\{2.047\}\end{array}$ \\
\hline Tax $\times$ Scale & & & $\begin{array}{l}-\mathbf{- 0 . 0 6 8 6}^{*} \\
\{-2.448\}\end{array}$ & $\begin{array}{l}-\mathbf{0 . 0 6 0 1} * \\
\{-2.174\}\end{array}$ \\
\hline Wage $\times$ Science & & & $\begin{array}{l}\text { 0.4331* } \\
\{3.387\} \\
\end{array}$ & $\begin{array}{l}\text { 0.4111* } \\
\{3.211\} \\
\end{array}$ \\
\hline $\begin{array}{l}\text { Prof } \times \text { Unempl } \\
\text { Size } \times \text { Distance }\end{array}$ & & & & $\begin{array}{c}-\mathbf{0 . 6 5 6 0 * * *} \\
\{-1.871\} \\
2.3668 * \\
\{3.577\}\end{array}$ \\
\hline $\begin{array}{l}\text { Log-likelihood } \\
\text { Chi-squared } \\
\text { Pseudo-R }{ }^{2}\end{array}$ & $\begin{array}{c}-2466.636 \\
331.902 \\
0.0630 \\
\end{array}$ & $\begin{array}{c}-2445.853 \\
373.468 \\
0.0710\end{array}$ & $\begin{array}{c}-2437.061 \\
391.052 \\
0.0743 \\
\end{array}$ & $\begin{array}{c}-2428.664 \\
407.846 \\
0.0775 \\
\end{array}$ \\
\hline
\end{tabular}

t-statistics in parenthesis

* Significant at 1 percent level

** Significant at 5 percent level

*** Significant at 10 percent level 
Table 3: Fraction (percentage) of investors that invest in a particular country, direct elasticities for GDP and TAX attributes

\begin{tabular}{|l|c|c|c|c|}
\hline Countries & Fractions & $\begin{array}{c}\text { Elasticities for } \\
\text { GDP attribute }\end{array}$ & $\begin{array}{c}\text { Elasticities for } \\
\text { TAX attribute }\end{array}$ & $\begin{array}{c}\text { Elasticities for } \\
\text { the WAGE } \\
\text { attribute }\end{array}$ \\
\hline Bulgaria & 3.84 & 0.206 & -0.783 & -0.231 \\
\hline Croatia & 2.54 & 0.317 & -1.205 & -0.237 \\
\hline Czech Republic & 15.21 & 0.824 & -0.617 & -0.520 \\
\hline Estonia & 7.93 & 0.081 & -0.678 & -0.479 \\
\hline Hungary & 12.92 & 0.747 & -0.890 & -0.513 \\
\hline Latvia & 3.76 & 0.123 & -0.554 & -0.488 \\
\hline Lithuania & 6.13 & 0.188 & -0.609 & -0.497 \\
\hline Poland & 30.17 & 1.817 & -0.571 & -0.530 \\
\hline Romania & 8.01 & 0.563 & -0.587 & -0.275 \\
\hline Slovakia & 4.33 & 0.337 & -0.846 & -0.57 \\
\hline Slovenia & 2.21 & 0.308 & -0.979 & -1.295 \\
\hline Ukraine & 2.94 & 0.549 & -0.614 & -0.197 \\
\hline
\end{tabular}

